\title{
DKK2 wt Allele
}

National Cancer Institute

\section{Source}

National Cancer Institute. DKK2 wt Allele. NCI Thesaurus. Code C111879.

Human DKK2 wild-type allele is located in the vicinity of $4 \mathrm{q} 25$ and is approximately $362 \mathrm{~kb}$ in length. This allele, which encodes dickkopf-related protein 2 , is involved in the negative regulation of Wnt signaling. 